\title{
Failure of anti tumor-derived endothelial cell immunotherapy depends on augmentation of tumor hypoxia
}

\author{
Annalisa Pezzolo${ }^{1}$, Danilo Marimpietri ${ }^{1}$, Lizzia Raffaghello ${ }^{1}$, Claudia Cocco ${ }^{1}$, Angela \\ Pistorio ${ }^{2}$, Claudio Gambini ${ }^{3}$, Michele Cilli ${ }^{4}$, Alberto Horenstein ${ }^{5}$, Fabio Malavasi ${ }^{5}$ \\ and Vito Pistoia ${ }^{1}$ \\ ${ }^{1}$ Laboratorio di Oncologia, Istituto Giannina Gaslini, Genova, Italy \\ 2 Unità di Epidemiologia e Biostatistica Istituto Giannina Gaslini, Genova, Italy \\ 3 Laboratorio di Anatomia Patologica Istituto Giannina Gaslini, Genova, Italy \\ ${ }^{4}$ Animal Research Facility, IRCCS-AOU San Martino-IST Istituto Nazionale per la Ricerca sul Cancro, Genova \\ ${ }^{5}$ Laboratorio di Immunogenetica, Università di Torino, Italy \\ Correspondence to: Annalisa Pezzolo, email: annalisapezzolo@ospedale-gaslini.ge.it \\ Keywords: epithelial-mesenchymal transition, hypoxia, neuroblastoma, tumor-derived endothelial cells, vascular mimicry \\ Received: March 14, 2014 \\ Accepted: May 26, 2014 \\ Published: May 26, 2014
}

This is an open-access article distributed under the terms of the Creative Commons Attribution License, which permits unrestricted use, distribution, and reproduction in any medium, provided the original author and source are credited.

\section{ABSTRACT}

We have previously demonstrated that Tenascin-C (TNC)+ human neuroblastoma (NB) cells transdifferentiate into tumor-derived endothelial cells (TDEC), which have been detected both in primary tumors and in tumors formed by human NB cell lines in immunodeficient mice. TDEC are genetically unstable and may favor tumor progression, suggesting that their elimination could reduce tumor growth and dissemination. So far, TDEC have never been targeted by antibody-mediated immunotherapy in any of the tumor models investigated.

To address this issue, immunodeficient mice carrying orthotopic NB formed by the HTLA-230 human cell line were treated with TDEC-targeting cytotoxic human (h)CD31, that spares host-derived endothelial cells, or isotype-matched mAbs. hCD31 mAb treatment did not affect survival of NB-bearing mice, but increased significantly hypoxia in tumor microenvironment, where apoptotic and proliferating TDEC coexisted, indicating the occurrence of vascular remodeling.

Tumor cells from hCD31 mAb treated mice showed i) up-regulation of epithelialmesenchymal transition (EMT)-related and vascular mimicry (VM)-related gene expression, ii) expression of endothelial (i.e. CD31 and VE-cadherin) and EMTassociated (i.e. Twist-1, N-cadherin and TNC) immunophenotypic markers, and iii) up-regulation of high mobility group box-1 (HMGB-1) expression. In vitro experiments with two NB cell lines showed that hypoxia was the common driver of all the above phenomena and that human recombinant HMGB-1 amplified EMT and TDEC transdifferentiation.

In conclusion, TDEC targeting with hCD31 mAb increases tumor hypoxia, setting the stage for the occurrence of EMT and of new waves of TDEC trans-differentiation. These adaptive responses to the changes induced by immunotherapy in the tumor microenvironment allow tumor cells to escape from the effects of hCD31 mAb.

\section{INTRODUCTION}

Tumor growth is critically dependent on adequate blood supply provided by newly formed endothelial micro-vessels (EM) [1-3]. Tumor cells themselves may contribute to vascularization by assembling into vascularlike channels according to a process referred to as vascular mimicry (VM). [4]. 
Neuroblastoma (NB) is an embryonal tumor arising from sympathetic neuronal progenitor cells that accounts for $15 \%$ of all pediatric cancer deaths [5-7]. We previously identified in primary NB tumors, as well as in orthotopic tumors formed in immunodeficient mice by different human NB cell lines, tumor-derived endothelial cells (TDEC) harboring $M Y C N$ amplification as the NB cells from which they originated [8-10]. More recently, we have identified perivascular NB progenitor cells expressing Tenascin C (TNC) on the cell surface, that displayed a high degree of plasticity and served as TDEC progenitors [10]. TDEC are genetically unstable and contribute to chemoresistance and tumor progression [11].

A hypoxic microenvironment is of pivotal importance for tumor growth. Hypoxia inducible factors regulate hypoxia responsive genes and play critical roles in tumor invasion, metastasis, and chemoresistance [12].

Epithelial-mesenchymal transition (EMT) is an embryonic process leading to the loss of cell-cell contact, repression of E-cadherin expression and increased cell motility. EMT can also occur in cancer cells, in which it is associated with resistance to chemotherapeutic drugs and radiation [13], and increased stemness, motility, invasiveness, as well as angiogenic and metastatic ability $[13,14]$. An hypoxic tumor microenvironment is one of the major EMT inducers $[15,16]$.

We have hypothesized that selective elimination of TDEC might reduce tumor growth. To address this issue, we have here selectively targeted TDEC in an orthotopic mouse model of human NB using a cytotoxic hCD31 mAb that does not react with mouse endothelial cells (mEC). Our findings demonstrate that hCD31 mAb-induced enhancement of tumor hypoxia activates i) EMT and ii) trans-differentiation of malignant cells into TDEC, both of which in turn account for the failure of such therapeutic approach.

\section{RESULTS}

\section{Tumor-derived endothelial cells (TDEC) contribute to tumor vascularization in an orthotopic mouse model of human NB}

Immunodeficient mice were inoculated in the adrenal gland with the human NB cell line HTLA-230 that, according to previous studies from our group [8-10], best mimics human NB growth and progression. Mice were treated with the hCD31 cytotoxic Moon-1 mAb [17] or isotype-matched control mAb. Supplementary Fig. 1 shows that the hCD31 mAb Moon-1 stained human TDEC, but not mEC.

All experiments were performed with tumors harvested eighteen days after NB cell inoculation. Such time point was selected on the ground of our previous studies showing that tumor-derived and mouse-derived EM, although displaying different kinetics of formation, are present in similar proportions after approximately two weeks from HTLA-230 NB cell inoculation [10].

Tumors from mice treated with hCD31 mAb $(n=7)$ were significantly smaller than control tumors $(n=7)(p=$ 0.047) (Fig. 1A), but treatment with hCD31 mAb did not prolong survival of tumor bearing $(\mathrm{n}=14)$ vs control $(\mathrm{n}=14)$ mice (Fig. 1B). Human EM density, assessed by hCD31 staining, decreased significantly $(\mathrm{p}=0.011)$ in orthotopic tumors from hCD31 mAb treated $(\mathrm{n}=7)$ vs control $(\mathrm{n}=7)$ mice (Fig. 2A). Accordingly, apoptotic hCD31 ${ }^{+} \mathrm{EM}$ (defined as EM containing at least three TUNEL ${ }^{+}$TDEC) increased significantly $(\mathrm{p}=0.036)$ in the former $(\mathrm{n}=5)$ vs the latter $(n=5)$ tumors (Fig. 2B and 2C, panel 1). Focal micro-vascular destruction and hemorrhagic areas were detected in tumors from hCD31 mAb treated mice (Fig. 2C, panel 2).

Double staining of NB tissue sections with hCD31 $\mathrm{mAb}$ and anti-Ki-67 mAb, that identifies proliferating cells, showed that $\mathrm{hCD} 31^{+}, \mathrm{Ki}-67^{+} \mathrm{EM}$ (defined as EM containing at least three $\mathrm{Ki}-67^{+} \mathrm{TDEC}$ ) increased significantly $(p=0.006)$ in tumors from hCD31 mAb treated vs control mice (Fig. 2B and 2C, panel 3), indicating the occurrence of human EM remodeling.

Mouse EM integrity was unaffected by hCD31 mAb treatment (Fig. 2C, panel 4) and mouse EM density was increased in tumors from hCD31 mAb treated $v s$ control mice $(\mathrm{p}<0.0001)$ (Fig. 2A).

\section{hCD31 mAb immunotherapy increases tumor hypoxia}

TDEC depletion induced by hCD31 mAb treatment may reduce blood supply and increase tumor hypoxia. Hypoxia inducible factor- $2 \alpha$ (HIF $2 \alpha$ ) is up-regulated in NB cells during hypoxic conditions and represents the most reliable hypoxic marker in NB [19]. In addition, HIF $2 \alpha$ has been associated with developing endothelium [20].We stained by immunofluorescence orthotopic NB tissue sections from hCD31 treated $(n=7)$ or control $(\mathrm{n}=7)$ mice with anti-HIF2 $\alpha \mathrm{mAb}$ [19]. The proportion of HIF $2 \alpha^{+}$cells was significantly higher in the former than in the latter tumors $(61.9 \pm 3.22 \%$ vs $20.7 \pm 6.18 \%, \mathrm{p}=0.0001)$ (Fig. 2C, panels 5 and 6).

In essence, TDEC contributed to $\mathrm{NB}$ vascularization since their targeting with hCD31 mAb reduced tumor size, decreased the number of human EM and increased hypoxia in tumor microenvironment. 

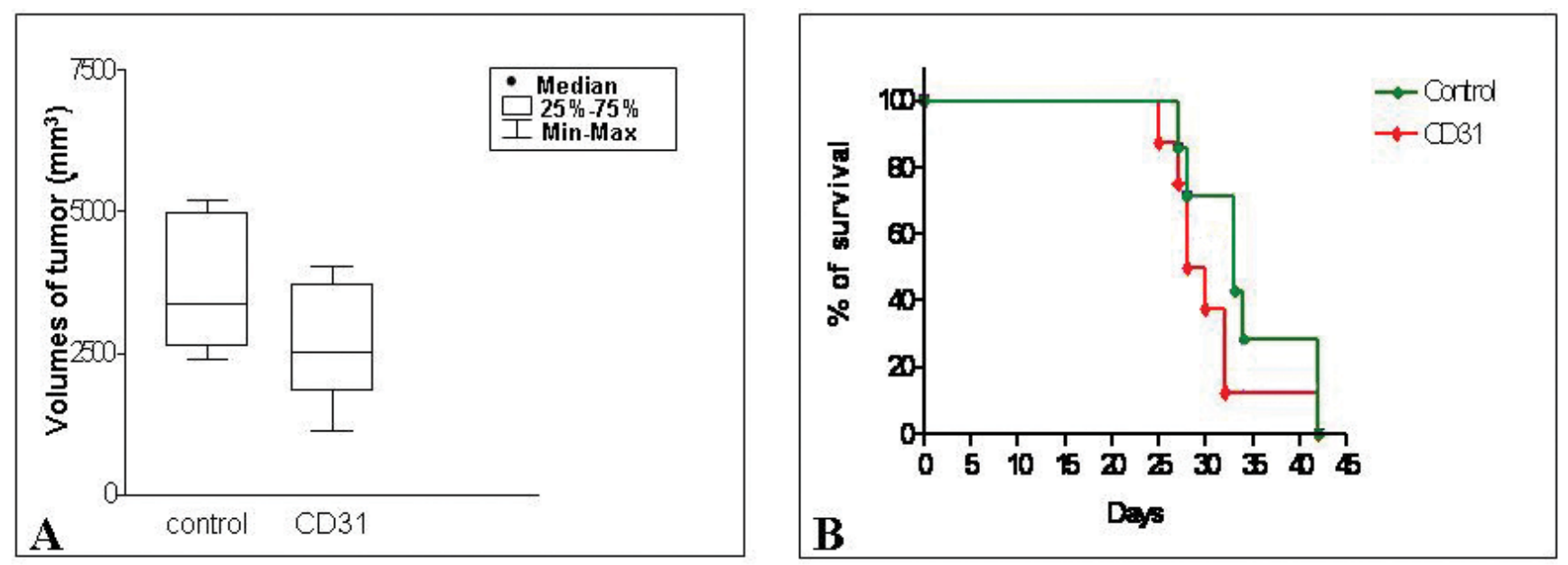

Figure 1: Effect of hCD31 mAb treatment on tumor growth and survival in orthotopic NB bearing mice . A) Tumors from mice treated with $\mathrm{hCD} 31 \mathrm{mAb}(\mathrm{n}=21)$ and sacrificed after 18 days from NB cell inoculation were significantly smaller than control tumors $(\mathrm{n}=21)(\mathrm{CD} 31$ vs control $\mathrm{p}=0.047)$. B) Treatment with hCD31 mAb had no effect on survival of tumor bearing mice which was superimposable to that of control mice.
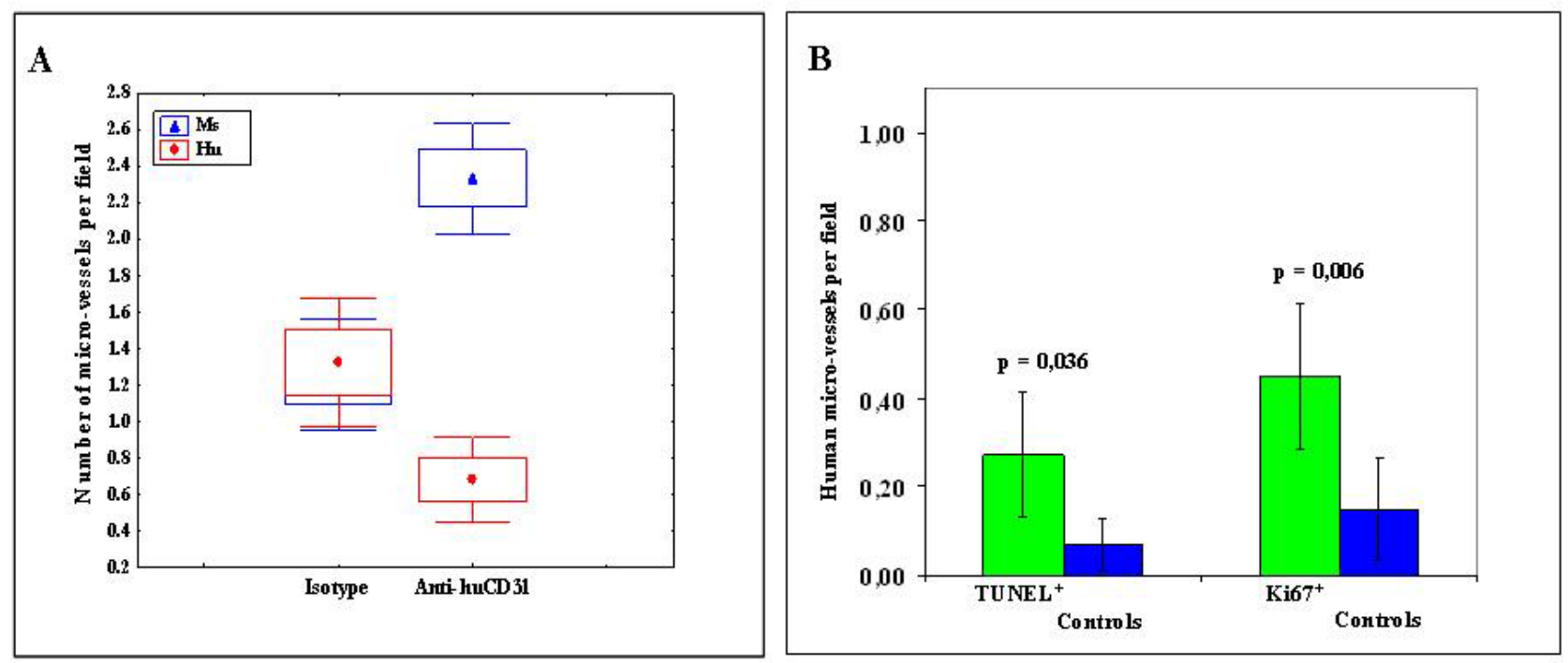

C
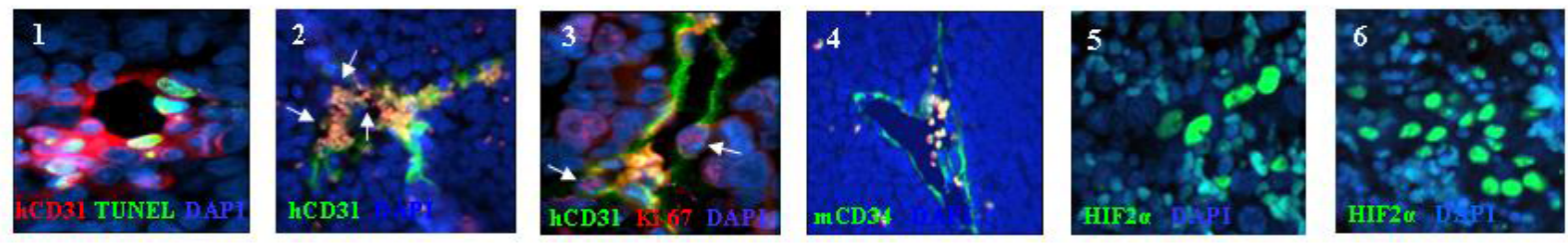

Figure 2: Endothelial micro-vessels in NB tumors from hCD31 mAb treated mice. A) hCD31+ (red) and mCD34+ $($ blue) $\mathrm{EM}$ per field in tumors from $\mathrm{hCD} 31 \mathrm{mAb} v s$ isotype treated mice harvested after 18 days from tumor cell inoculation. Small circles represent median values, boxes represent $25 \%-75 \%$ and bars represent minimum and maximum values. B) Apoptotic (TUNEL ${ }^{+}$) and proliferating $\left(\mathrm{Ki}-67^{+}\right)$human $\mathrm{EM}$ increased significantly $(\mathrm{p}=0.036$ and $\mathrm{p}=0.006$, respectively) in tumors from $\mathrm{hCD} 31 \mathrm{mAb}$ treated $v s$ control mice. Columns represent mean values; bars represent 95\% Confidence Intervals. C) Immunofluorescence analysis of tumors from hCD31 mAb treated mice: 1) double staining for hCD31 mAb (red) and TUNEL (green) detects human apoptotic EM, 2) focal microvascular destruction (white arrows) of hCD31 $1^{+} \mathrm{EM}$ (green); 3) double staining for hCD31 mAb (green) and Ki-67 (red) detects human proliferating $\mathrm{EM}$ (white arrows); 4) viable $\mathrm{mCD}^{+} 4^{+} \mathrm{EM}$ (green); 5, 6) $\mathrm{NB}$ tissue sections from control and hCD31 mAb treated mice stained with anti-hypoxia inducible factor- $2 \alpha$ (HIF $2 \alpha)$ mAb. NB tumors harvested after 18 days were studied ( $n=7$ tumors/group). Images in $\mathrm{C}$ illustrate representative data from one of at least three independent experiments. 


\section{hCD31 mAb immunotherapy up-regulates expression of human pro-angiogenic genes in NB cells}

We next investigated the angiogenic phenotype of tumors from $\mathrm{hCD} 31 \mathrm{mAb}$ treated $(\mathrm{n}=4)$ vs control $(\mathrm{n}=4)$ mice using PCR arrays specific for selected human or mouse angiogenic transcripts. hCD31 mAb treatment caused up-regulation (range 1,000-160,000 fold) of the expression of different human pro-angiogenic genes including CCL11, CXCL3, CXCL5, cadherin 5 (CDH5), also known as vascular endothelial (VE)-cadherin, collagen type IV $\alpha 3$ (COL4A3), vascular endothelial growth factor (VEGF), platelet derived growth factor-A
(PDGFA), fibroblast growth factor-1 (FGF1), TNF and IL-6 (Fig. 3A, black bars). High expression of these proangiogenic genes, the majority of which are not speciesspecific, likely accounts for the increased numbers of mouse-derived EM in NB tumors from h-CD31 mAb treated mice.

Two distinctive "signatures" related to VM [21] and epithelial mesenchymal transition (EMT) [22-24], respectively, were identified. In particular, VM-related transcripts included VE-cadherin (CDH5), collagen IV (COL4A), endothelial differentiation receptor (EDG1), IL-6, TNF-induced protein 2 (TNFAIP2), the matrix metalloproteinase MMP2, jagged-1 (JAG1), i.e. the ligand for the receptor Notch-1, and thrombospondin-1 (THBS1)
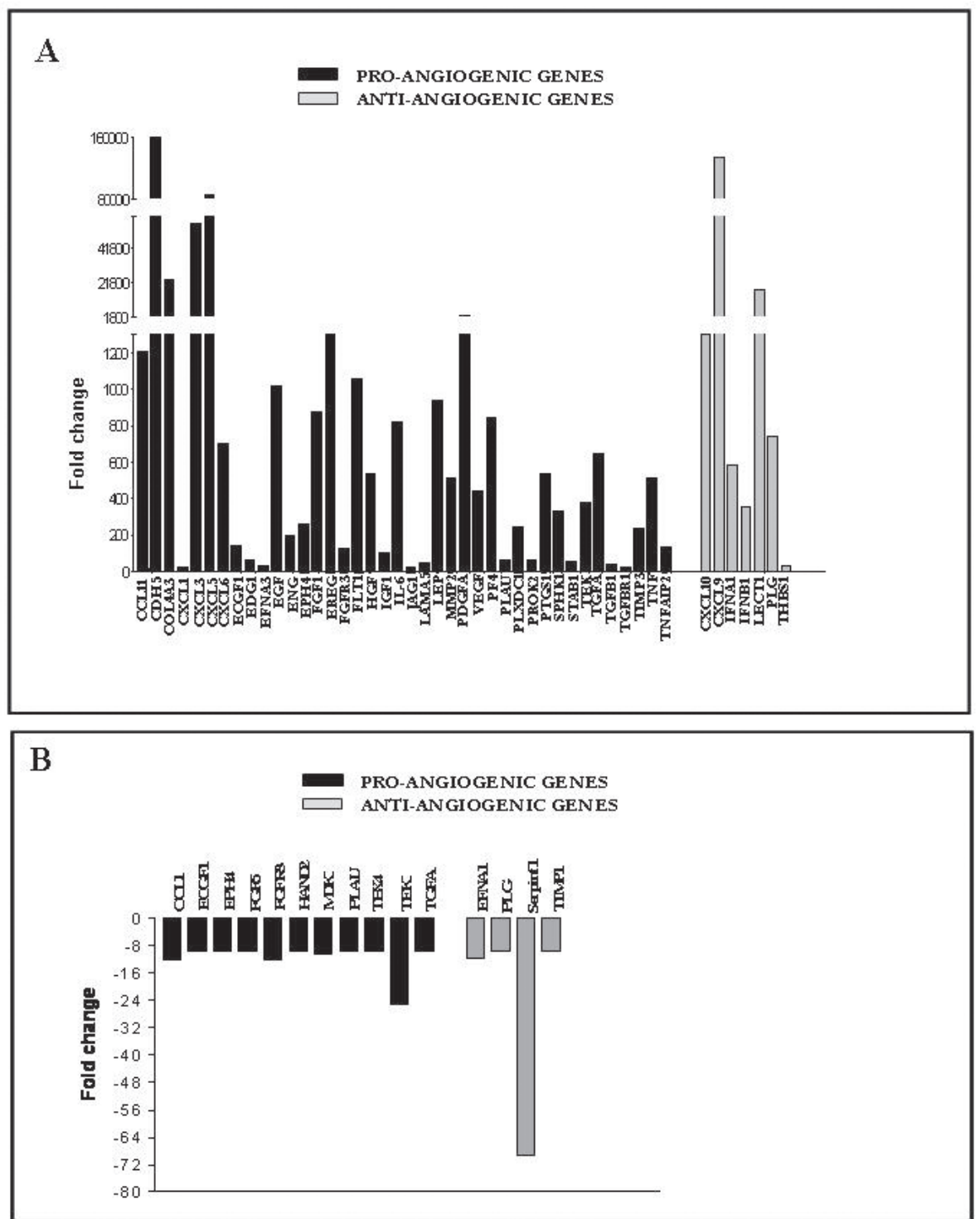

Figure 3: Human and mouse angiogenic gene expression in orthotopic NB tumors from anti-hCD31 mAb treated mice. $\mathrm{NB}$ tumors from $\mathrm{hCD} 31 \mathrm{mAb}$ treated mice were harvested after 18 days. A) Human angiogenesis PCR array analysis of one representative NB tumor (out of four) from hCD31 mAb treated $v s$ control mice. Pro-angiogenic genes, black bars; anti-angiogenic genes, grey bars. B) Mouse angiogenesis PCR array analysis of one representative NB tumor (out of four) from anti-hCD31mAb treated $v s$ control mice. Proangiogenic genes, black bars; anti-angiogenic genes, grey bars. Assays for each experiment were performed in triplicate. 
[21]. EMT-related transcripts included epidermal growth factor (EGF), hepatocyte growth factor (HGF), insulin growth factor-1 (IGF-1), TNF, CXCL5, IL-6, FGF-1, PDGFA and MMP2 [22-25].

Expression of some human anti-angiogenic genes including interferon (IFN)A1, IFNB1, CXCL9, CXCL10 and Leukocyte cell derived chemotaxin-1 (LECT1) was

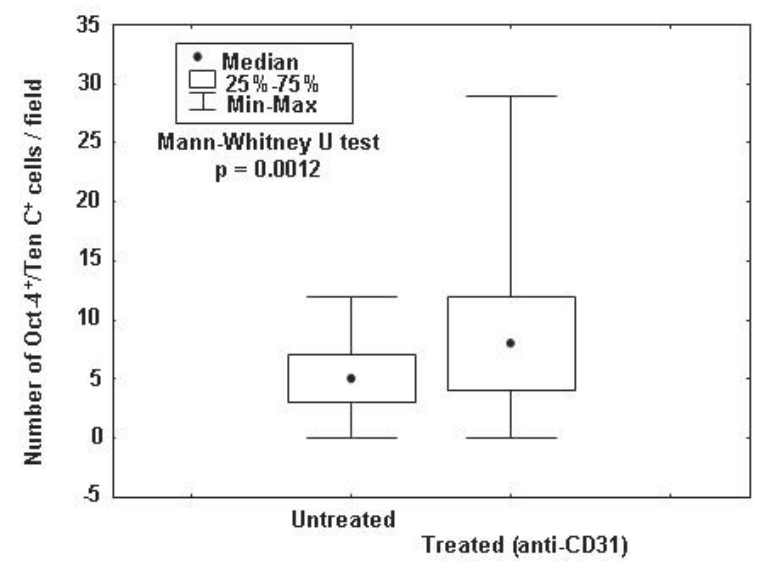

Figure 4: $\mathrm{TNC}^{+} / \mathrm{Oct}^{+} 4^{+} \mathrm{NB}$ cell enumeration in tumors from hCD31 mAb treated mice. NB tumors from hCD31 $\mathrm{mAb}$ treated $(\mathrm{n}=5)$ or control $(\mathrm{n}=5)$ mice were harvested after 18 days. Numbers of $\mathrm{TNC}^{+} /$Oct- $4^{+}$cells, that represent TDEC progenitors, per field were assessed by immunofluorescence. Small circles represent median values, boxes represent $25 \%$ $75 \%$ and bars represent minimum and maximum values. also increased following hCD31 treatment (Fig. 3A, grey bars), perhaps in response to massive up-regulation of pro-angiogenic genes. In contrast, expression of mouse angiogenesis related genes was unaffected or dampened by hCD31 treatment (Fig. 3B).

We next asked whether human TDEC targeting altered the number and/or proliferative status of $\mathrm{TNC}^{+} /$ Oct- $4^{+} \mathrm{NB}$ vascular progenitor cells [10], identified by TNC surface staining, and $M Y C N$ FISH. $\mathrm{TNC}^{+} \mathrm{NB}$ cells carrying $M Y C N$ amplification, that showed a perivascular distribution [10], increased significantly in tumors from hCD31 treated $(\mathrm{n}=5)$ vs control $(\mathrm{n}=5)$ mice $(\mathrm{p}=0.0012)$ (Fig. 4). Furthermore, the fraction of proliferating $\left(\mathrm{Ki}-67^{+}\right)$ $\mathrm{TNC}^{+}$cells was $8 \%(11 / 141)$ in hCD31 treated and 3\% $(5 / 154)$ in control mice $(p<0.0001 ; 95 \%$ Binomial Exact Confidence Interval).

Thus, TDEC remodeling triggered by hCD31 mAbdriven depletion of TDEC caused an increase of cycling $\mathrm{TNC}^{+}$vascular progenitor NB cells, likely setting the stage for TDEC replenishment.

\section{NB vascular progenitor cells express the neural Tenascin C isoform A1, A2, A4, B}

TNC is encoded by a single gene and its expression is regulated by a single promoter [26]. Structurally and

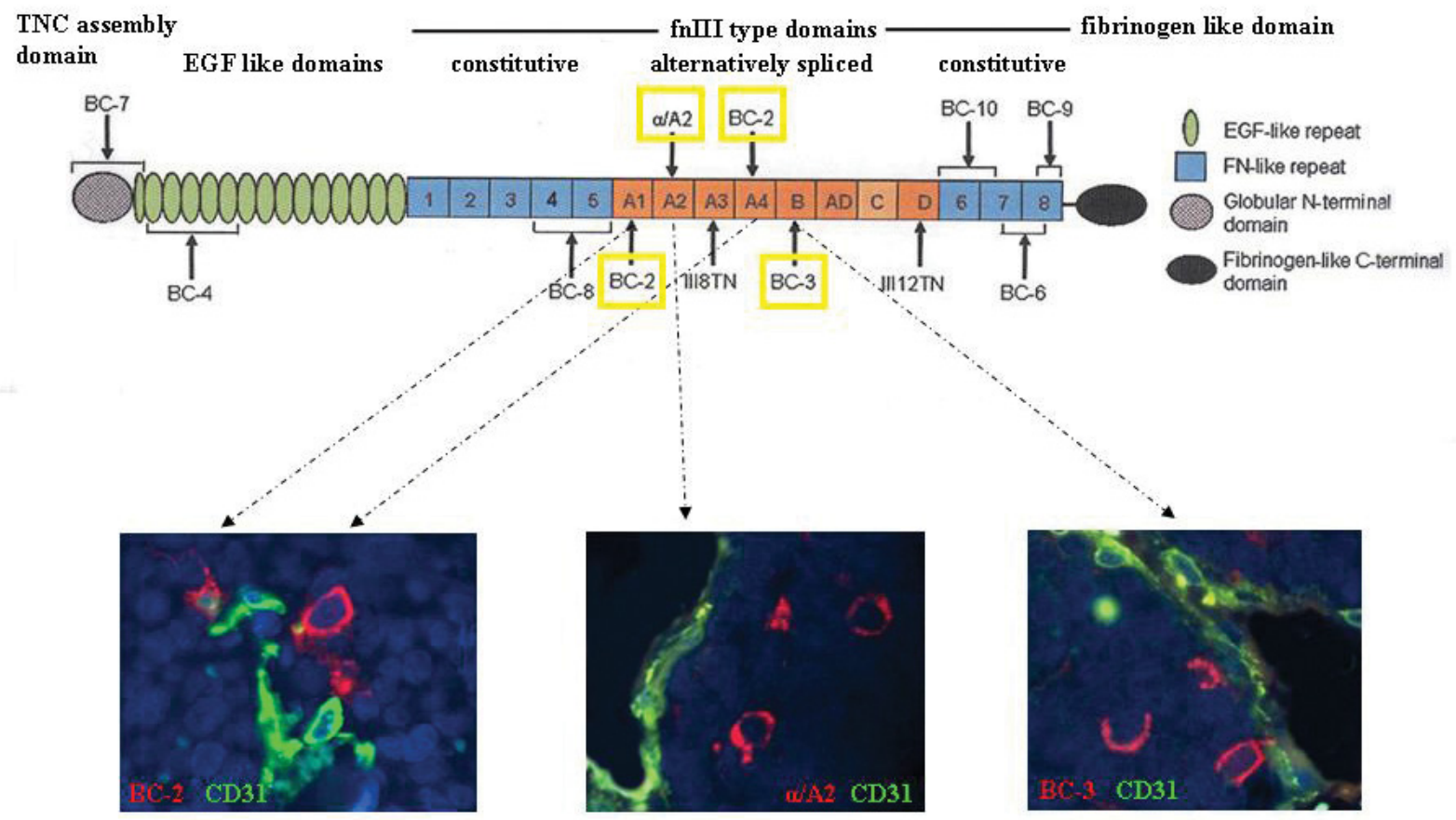

Figure 5: Expression of the large TNC isoform containing the A1, A2, A4, and B FnIII domains. Upper panel shows schematic representation of the TNC protein. The domain structure of TNC comprising N-terminal assembly domain is followed by epidermal growth factor (EGF)-like repeats, the fibronectin type III (fnIII)-like repeats and the fibrinogen-like domain. The fnIII region consists of eight conserved repeats, designated 1 to 8, and up to nine alternatively spliced fnIII repeats designated as letters A to D. Lower panels show the immunofluorescence images after double staining of orthotopic tumor tissue sections formed by HTLA-230 cells in immunodeficient mice ( $\mathrm{n}=5$ ) with BC-2 (A1 and A4 specific), $\alpha / \mathrm{A} 2$ (A2 specific) and BC-3 (B specific) mAbs (all in red), and hCD31 $\mathrm{mAb}$ (green). Representative images of one out of three experiments performed are shown. 
functionally different human TNC isoforms are generated by alternative splicing of the TNC transcript [26]. TNC is a multi-modular protein with a cysteine-rich assembly domain, epidermal growth factor (EGF)-like domains, several fibronectin type III (FnIII) domains, and a fibrinogen-like domain [25]. Up to six additional domains can be inserted between the fifth and sixth domain by alternative splicing domains (A1 to A4, B, C and D) [18, 27]. To identify what isoform(s) of TNC was expressed by NB progenitor cells, we used a series of murine mAbs specific for different alternatively spliced domains of this molecule [18]. Only the TNC isoform containing the alternatively spliced FnIII domains A1, A2, A4, and B was consistently detected in $\mathrm{TNC}^{+} \mathrm{NB}$ vascular progenitor cells present in orthotopic NB tumors $(n=4)$ (Fig. 5). This large TNC isoform is selectively expressed in neural stem/ progenitor cells [28].

\section{hCD31 mAb immunotherapy induces epithelial- mesenchymal transition in orthotopic NB tumors}

Detection of an EMT "signature" in NB cells from hCD31 mAb treated mice prompted experiments in which tumor tissue sections were stained with mAbs to Twist-1, the master regulator of EMT [29], N-cadherin and E-cadherin.

Most tumor cells from control mice $(n=7)$ showed cytoplasmic expression of Twist-1 $(83 \pm 5 \%)$, consistent with its transcriptional inactive state [29] (Fig. 6A, panel 1). The same cells expressed E-cadherin ( $98 \pm 2 \%$ ) (Fig. 6A, panel 3) but not N-cadherin (Fig. 6A, panel 5).

In contrast, tumors from hCD31 mAb treated mice
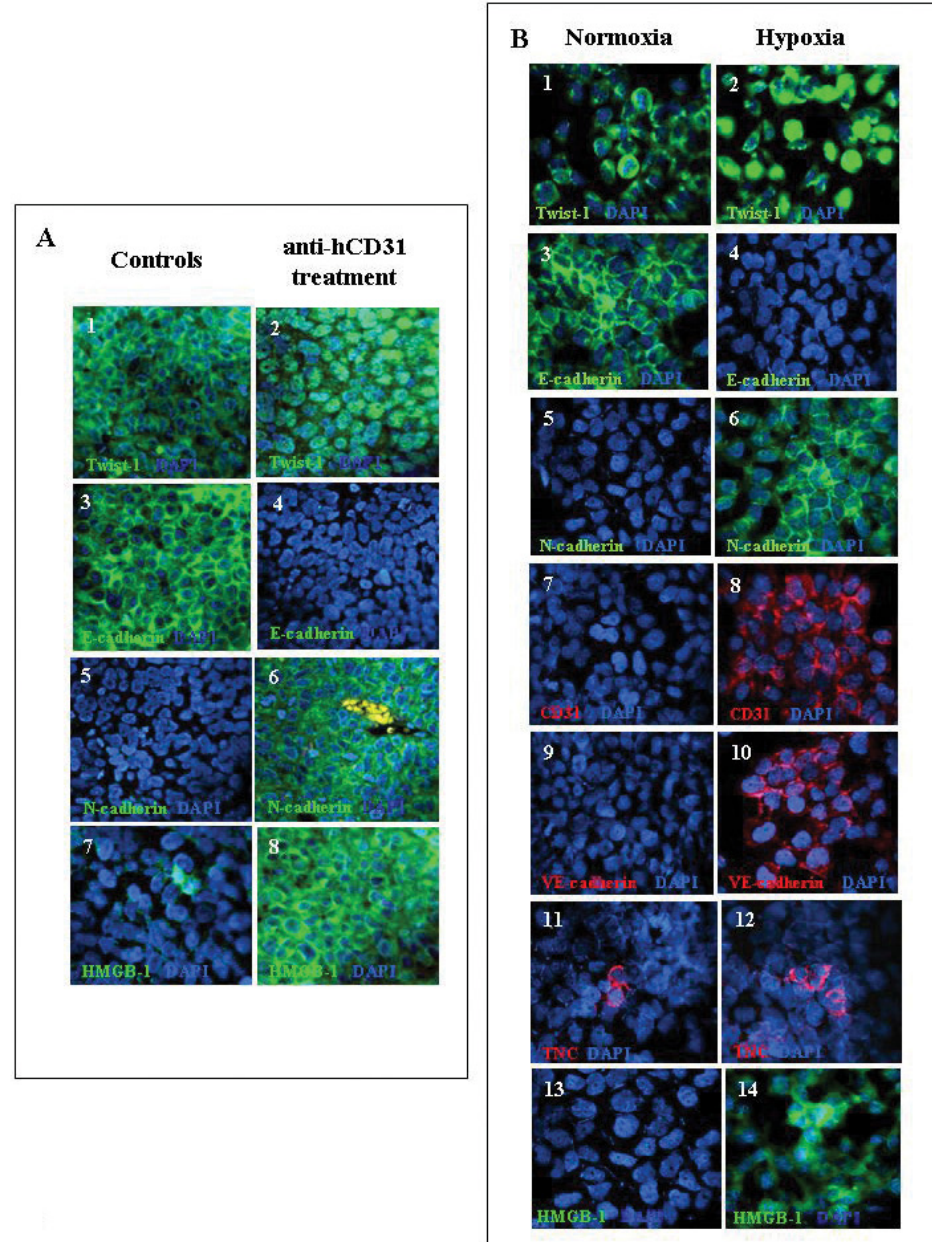

Figure 6: Expression of EMT proteins in orthotopic NB tumors from hCD31 mAb treated mice and in human NB cell lines incubated in vitro under normoxia or hypoxia. . A) Immunofluorescent staining of paraffin sections of orthotopic NB tumors from mice treated with hCD31 $(n=7)$ or control mice $(n=7)$. Staining for Twist-1 $(1,2)$, E-cadherin $(3,4)$, N-cadherin $(5,6)$, HMGB-1 (7, 8). The Figure shows one representative experiment out of the four performed.. B) HTLA-230 cells were incubated in hypoxic or normoxic environment for 48h. Expression of EMT-related and endothelial markers, as well as of HMGB-1, was detected by immunofluorescent staining. Staining for Twist-1 (1, 2), E-cadherin $(3,4)$, N-cadherin $(5,6)$, hCD31 $(7,8)$, VE-Cadherin $(9,10)$, TNC $(11,12)$ and HMGB$1(13,14)$. Nuclei are stained with DAPI (blue). Original magnification 40x. One representative experiment out of the four performed is shown. 
$(n=7)$ showed in most of the cells nuclear expression of Twist-1 (79 $\pm 7 \%)$, indicative of ongoing transcriptional activity [29] (Fig. 6A, panel 2). In addition, NB cells displayed expression of $\mathrm{N}$-cadherin $(98 \pm 3 \%)$ (Fig. 6A, panel 6) but not E-cadherin (Fig. 6A, panel 4). These results confirmed the onset of EMT [30] in tumors from hCD31 mAb treated mice.

Hypoxia may up-regulate the expression of highmobility group box protein-1 (HMGB-1) [31], that acts as extracellular signaling molecule during inflammation, angiogenesis, cell differentiation, cell migration, and tumor metastasis [32-35]. Indeed, $\mathrm{HMGB}-1^{+}$cells were significantly increased in tumors from hCD31 mAb treated $(\mathrm{n}=7)$ vs control $(\mathrm{n}=7)$ mice $(77.3 \pm 8.2 \%$ vs $11.0 \pm 2.7 \%, \mathrm{p}=$ 0.0004). HMGB-1 was always detected in the cytoplasm of NB cells (Fig. 6A, panels 7 and 8), suggesting a role of this molecule in the stimulation of cell motility [32-35].
In vitro culture of HTLA-230 $\mathrm{NB}$ cells under hypoxic conditions induces expression of epithelial mesenchymal transition-related and endothelial cell-related markers, as well as of HMGB-1

In order to investigate the in vitro conditions allowing expression of EMT-related and endothelial markers in NB cells, HTLA-230 cells were incubated in hypoxia $\left(1 \% \mathrm{O}_{2}\right)$ or normoxia for $24-72 \mathrm{~h}$. In four different experiments, cytoplasmic Twist-1 was detected in $80 \pm 13 \%$ cells under normoxia only (control) (Fig. 6B, panel 1), whereas nuclear Twist- 1 was detected in $76 \pm 5 \%$ HTLA230 cells under hypoxia only (Fig. 6B, panel 2). Hypoxia induced down-regulation of E-cadherin $(<1 \%)$, while strong basal expression of the latter marker (mean \pm SD $82 \pm 7 \%$ ) was detected in normoxic cells (Fig. 6B, panels
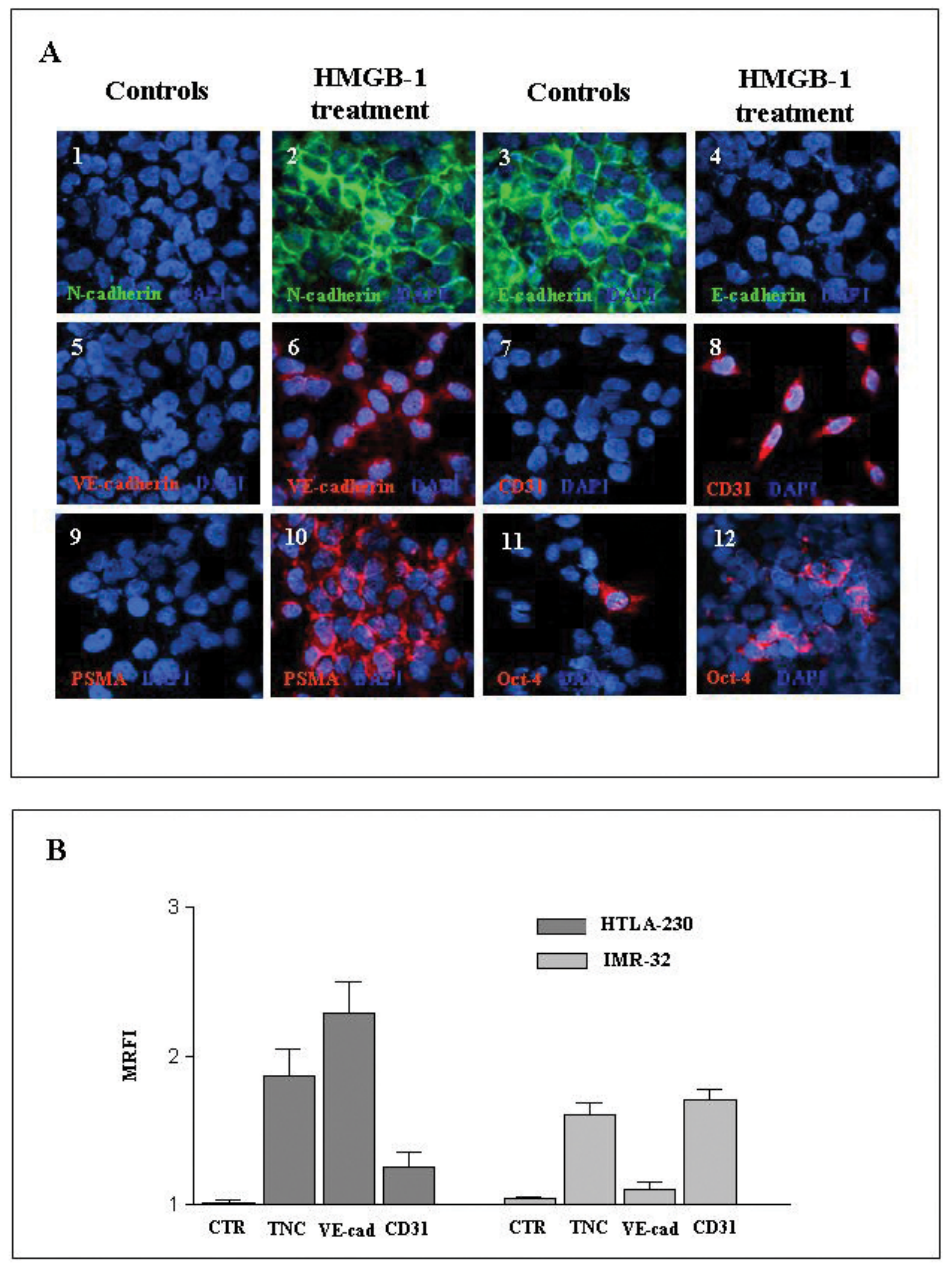

Figure 7: Incubation of NB cell lines in vitro with HMGB-1 induces expression of EMT-related and endothelial markers. A) Immunofluorescence staining of cytospins of the HTLA-230 cell line cultured for $48 \mathrm{~h}$ in the absence or presence of human recombinant HMGB-1 protein $(10 \mu \mathrm{g} / \mathrm{ml})$. Cytospins were stained for $\mathrm{N}$-cadherin $(1,2)$, E-cadherin $(3,4)$, VE-cadherin $(5,6)$, CD31 $(7,8)$, PSMA $(9,10)$ and Oct-4 $(11,12)$. Nuclei are stained with DAPI (blue). Original magnification 40x. One representative experiment out of the four performed is shown..B) Expression of TNC, VE-cadherin and CD31 were evaluated by flow cytometry in HTLA-230 and IMR-32 cell lines cultured in the presence or absence of HMGB-1 as above. Results are expressed as MRFI and represent means \pm SD from three independent experiments. 
3 and 4, respectively). Conversely, hypoxia induced de novo expression of $\mathrm{N}$-cadherin (mean $\pm \mathrm{SD} 85 \pm 10 \%$ ) that was detected in less than $1 \%$ normoxic cells (Fig. $6 \mathrm{~B}$, panels 5 and 6). Under hypoxia, HTLA-230 cells acquired expression of the endothelial-specific markers CD31 (mean \pm SD $35 \pm 9 \%$ ) (Fig. 6B, panels 7 and 8 ) and VEcadherin (mean \pm SD $72 \pm 6 \%$ ) (Fig. 6B, panels 9 and 10), that were undetectable in normoxic cells. Furthermore, $\mathrm{TNC}^{+}$cells, that serve as TDEC progenitors [10], were significantly increased in hypoxic compared to normoxic $\mathrm{NB}$ cells (means $\pm \mathrm{SD}: 20.0 \pm 4.3 \%$ vs $10.0 \pm 2.7 \%$, p= 0.006 ) (Fig. 6B, panels 11 and 12). Finally, most HTLA230 cells cultured in hypoxia acquired the expression of HMGB-1, that was virtually undetectable in normoxic cells.

These data establish definitively that hypoxia induces expression of EMT-related and endothelial markers in NB cells.

\section{HMGB-1 mimics hypoxia in vitro}

Since HMGB-1 induces EMT in lung [32] and renal [34] fibrosis, we finally investigated whether HMGB1 behaved similarly in our human NB models under normoxic conditions. In four different experiments, HTLA-230 cells were cultured with HMGB-1 for 2472 h. Fig. 7A shows that HTLA-230 cells cultured with HMGB-1 acquired the expression of $\mathrm{N}$-cadherin and lost that of E-cadherin, indicative of an ongoing EMT. The same cells expressed de novo VE-cadherin (mean $\pm \mathrm{SD}$ $87 \pm 4.3 \%$ ), CD31 (mean \pm SD $30 \pm 2.5 \%$ ), and PSMA [10] (mean \pm SD $75 \pm 1 \%$ ), witnessing the occurrence of transendothelial differentiation of NB cells. Accordingly, TDEC progenitors expressing Oct-4 both in the nucleus and the cytoplasm were doubled in HTLA-230 cells incubated with HMGB-1 compared to control (means \pm SD: $18.0 \pm 3 \%$ vs $9.0 \pm 3.2 \%, \mathrm{p}=0.008)$ (Fig. $7 \mathrm{~A}$ ).

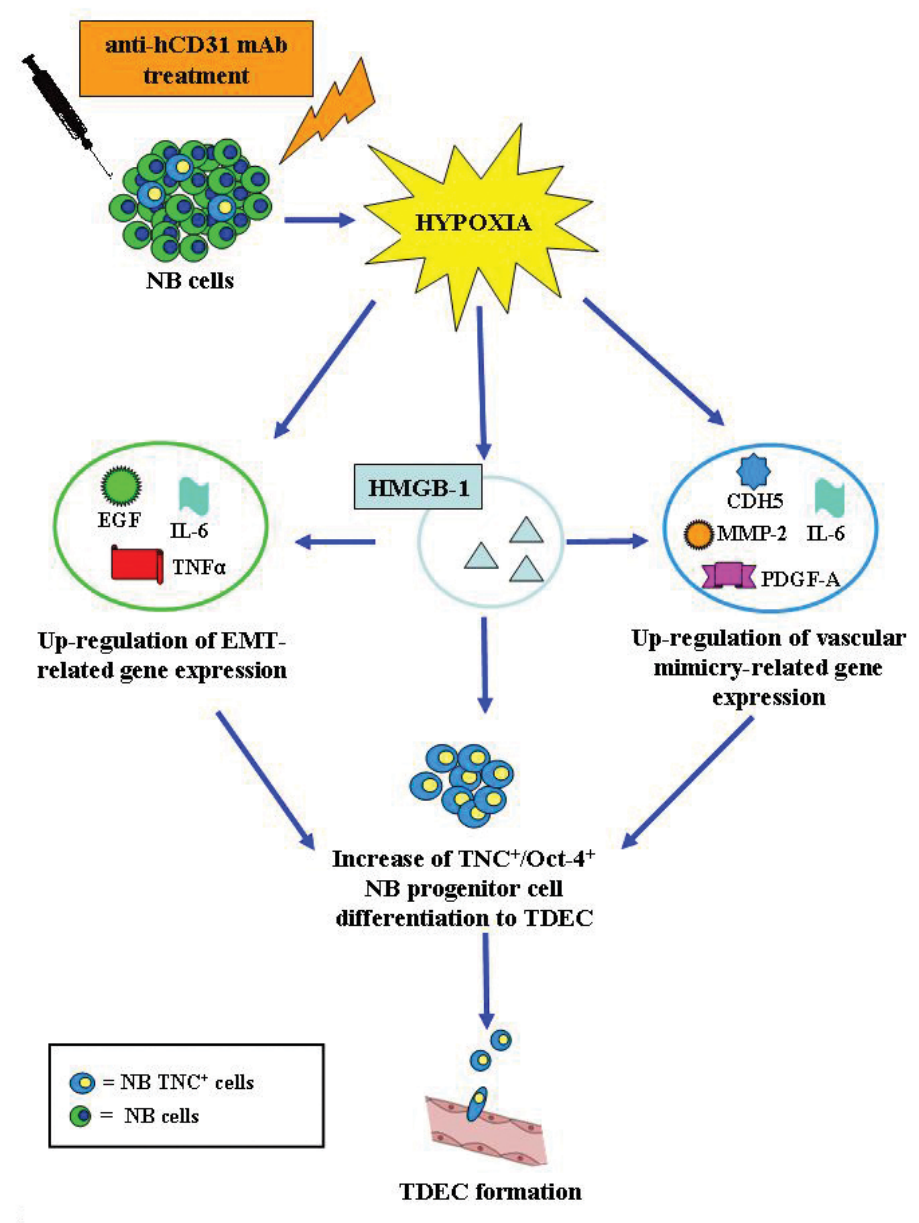

Figure 8: A model for hypoxia-driven EMT and trans-endothelial differentiation of NB cells. TDEC targeting with cytotoxic hCD31 mAb enhances tumor hypoxia, which in turn induces EMT and endothelial trans-differentiation of tumor cells. Both of the latter phenomena increase the proportion of $\mathrm{TNC}^{+} / \mathrm{Oct}-4^{+} \mathrm{NB}$ cells, that differentiate into TDEC responsible for the vascular remodeling observed in tumors from hCD31 treated mice. In addition, hCD31 mAb-driven hypoxia promotes in NB cells expression of HGMB-1 that induces by itself EMT and endothelial trans-differentiation of tumor cells, thus mimicking the effects of hypoxia and serving as an amplification loop. All of these mechanisms in combination account for the refractoriness of NB tumors to TDEC targeting with hCD31 mAb. 
When HTLA-230 and IMR-32 NB cell lines were treated with HMGB-1 and analyzed by flow cytometry $(\mathrm{n}=3$ experiments), both cell lines variably up-regulated the expression of TNC, VE-cadherin and CD31, thus confirming that HMGB-1 induced the acquisition of EMTrelated (TNC) and endothelial (VE-cadherin and CD31) markers (Fig. 7B).

\section{DISCUSSION}

Primary NB tumors may contain a variable number (range 20-78\%) of TDEC carrying the same genomic alteration as tumor cells [10]. $\mathrm{TNC}^{+}$perivascular $\mathrm{NB}$ cells serving as TDEC progenitors have been identified in primary NB samples, metastatic bone marrow aspirates, NB cell lines, and orthotopic tumors formed by these cell lines in immunodeficient mice [8-10].

Studies aimed at targeting TDEC, that are genetically unstable and contribute to tumor progression [11], have shown that thalidomide, sirolimus, curcumin, isoxanthohumol or resveratrol inhibited TDEC formation in various pre-clinical models [36]. Differentiation of $\mathrm{CD}_{133^{+}}$glioblastoma stem cells into TDEC [37-39] was unaffected by anti-VEGF mAb, but blocked by $\gamma$-secretase inhibition or Notch-1 silencing [39].

Here we have targeted for the first time human TDEC in vivo with the cytotoxic hCD31 mAb Moon-1, taking advantage of its high specificity witnessed by the lack of any reactivity with host-derived EC. Significant decrease of TDEC due to apoptosis and reduction of tumor size unambiguously proved that TDEC contributed to NB growth. However, tumors harvested at the end of immunotherapy cycles displayed active vascular remodeling, as shown by detection of proliferating TDEC. In this respect, treatment with VEGF inhibitors or VEGF gene inactivation in preclinical mouse models of cancer were previously found to increase tumor invasiveness and metastasis, as well as EC proliferation, that could play a role in a putative rebound dampening anti-angiogenic treatment efficacy [40-42].

Hypoxia-inducible factor renders cells capable of surviving in hypoxia and stimulates endothelial cell growth [43]. On one hand, hypoxia inhibits the mTOR pathway, mTOR-dependent translation of HIF-1 and prevents senescent phenotype [44]. On the other hand, hypoxia strongly posttranslationally induces HIF-1, which increases secretion of mitogens and cytokines, markers of cellular senescence and promotes it [43]. We reasoned that hypoxia could drive vascular remodeling in NB tumors from mice treated with hCD31 mAb $[45,46]$. Indeed, a highly significant increase of HIF-2 $\alpha$ expression was detected in tumors from $\mathrm{hCD} 31 \mathrm{mAb}$ treated mice, indicating that TDEC targeting resulted into generation of a strongly hypoxic tumor microenvironment. Hypoxia was previously shown to induce expression of VM-related genes [21]. Indeed, up-regulation of the expression of
VM-related and other pro-angiogenic genes was detected by PCR array in tumors from hCD31 mAb treated mice. Angiogenic factors, which are produced by tumor cells in response to hypoxia, reduce the pro-apoptotic potency of chemotherapy on endothelial cell [47]. By activating hypoxic response in tumor cells, antiangiogenic therapy may promote metastasis and invasion [47].

Hypoxia is also an inducer of EMT, characterized by loss of cell junction and gain of migratory behavior $[30,33]$. Twist-1 is a basic helix-loop-helix transcriptionfactor that promotes EMT [48-50] through i) repression of E-cadherin [48], leading to disassembly of adherens junctions and increased migratory potential [50], and ii) up-regulation of mesenchymal markers, as N-cadherin and $\mathrm{TNC}$ [49]. In our experiments, tumors from hCD31 mAb treated mice showed nuclear translocation of Twist-1, lost E-cadherin expression and acquired $\mathrm{N}$-cadherin expression, indicating the occurrence of hCD31 mAbinitiated EMT. These findings were corroborated by the results of PCR array analysis of tumors from $\mathrm{hCD} 31 \mathrm{mAb}$ $v s$ isotype treated mice showing the presence of an EMTrelated "signature" in the former tumors.

Damage associated molecular patterns (DAMPs) are released by dying cells [51]. The main DAMP is HMGB-1 [52, 53], that promotes angiogenesis, evasion of programmed cell death, self-sufficiency in growth signals, insensitivity to inhibitors of growth, autophagy, and tissue invasion and metastasis [52-54]. Tumor angiogenesis is enforced by autocrine regulation of HMGB-1 in EC through increased expression of key proangiogenic genes as PDGF-A, FGF and MMP-2 [55], that we found to be strongly up-regulated in tumors from hCD31 mAb treated mice. We asked whether the latter tumors expressed HMGB-1. Indeed, most tumor cells from hCD31 mAb treated mice expressed HMGB-1, that was barely detectable in control tumors, suggesting that hypoxia augmented by hCD31 mAb treatment upregulated HMGB-1 [52-54].

The results of in vivo experiments were confirmed by in vitro studies with NB cell lines incubated in hypoxia. These cells i) acquired expression of $\mathrm{N}$-cadherin and nuclear Twist-1 and lost that of E-cadherin, ii) expressed de novo the EC-related markers CD31 and VE-cadherin, as well as HMGB-1, and iii) up-regulated the expression of TNC that, beside representing an EMT marker [56], identifies NB TDEC progenitors [10]. The latter finding is consistent with the significant increase of $\mathrm{TNC}^{+} /$Oct$4^{+}$cycling TDEC progenitors observed in tumors from $\mathrm{hCD} 31 \mathrm{mAb}$ treated mice.

HMGB-1 can induce EMT in human kidney tubular epithelial cells [34] and mouse alveolar epithelial cells [32]. We found that HMGB-1 induced expression of EMT and $\mathrm{EC}$ markers in NB cells cultured in normoxia, thus mimicking the effects of hypoxia. HMGB-1 conceivably bound to NB cells through Toll-like receptor 4 (TLR-4), and/or RAGE [57], that have been shown in previous 
studies to be expressed by these cells [58]. It is tempting to speculate that HMGB-1 synergizes with hypoxia subserving the same or similar functions in less hypoxic or normoxic areas of the tumor mass.

Taken together, our results indicate that hypoxiadriven enhancement of VM and onset of EMT represent adaptive mechanisms to the perturbation of tumor microenvironment caused by hCD31 mAb treatment. Notably, in this respect, nuclear translocation of Twist-1 [29] initiated VM in hepatocellular [29, 50] and colorectal [59] carcinomas, showing that EMT and VM are linked.

Additional mechanisms beside hypoxia may contribute to the onset of EMT in tumors from hCD31 $\mathrm{mAb}$ treated mice. IL-6, whose expression was upregulated in the latter tumors, is a well known inducer of EMT and mediates trastuzumab resistance in breast cancer [60]. Anaphylotoxins as C3a and C5a, generated in our study by hCD31 mAb-mediated complement activation, regulate EMT in non-malignant disease models [61, 62].

In conclusion, we propose the following model (Fig. 8). TDEC targeting with cytotoxic hCD31 mAb enhances tumor hypoxia, which in turn induces EMT and promotes endothelial trans-differentiation of tumor cells. Both of the latter phenomena increase the proportion of $\mathrm{TNC}^{+} /$ Oct $-4^{+}$NB cells, that differentiate into TDEC responsible for the vascular remodeling observed in tumors from hCD31 mAb treated mice. In addition, hCD31 mAbdriven hypoxia promotes in NB cells expression of HGMB-1 that induces by itself EMT and endothelial trans-differentiation of tumor cells, thus serving as an amplification loop of hypoxia (Fig. 8). Altogether these mechanisms account for the refractoriness of NB tumors to TDEC targeting with hCD31 mAb. A potential strategy to exploit hypoxia for therapeutic purposes might be to combine an antiangiogenic treatment with inactive prodrugs that are activated by hypoxia [47].

\section{METHODS}

\section{Orthotopic mouse model of human neuroblastoma}

Seven/eight week old female athymic nude (nude) nude) mice from Harlan Laboratories (Harlan Italy, S. Pietro al Natisone, Italy) were housed in sterile enclosures under specific pathogen-free conditions. Mice were subjected to laparotomy, and injected with HTLA-230 cells $\left(1.5 \times 10^{6}\right.$ cells in $20 \mu \mathrm{l}$ of saline solution $)$ in the left adrenal gland [10]. Mice were anesthetized with ketamine (Imalgene 1000, Merial Italia SpA., Milan, Italy) and sacrificed by cervical dislocation. All procedures involving animals were performed in the respect of the National and International current regulations (D.lvo 27/01/1992, $\mathrm{n}^{\circ}$ 116, European Economic Community Council Directive 86/609, OJL 358, Dec. 1, 1987) and were reviewed and approved by the licensing and Ethical Committee of the IRCCS-AOU San Martino-IST National Cancer Research Institute, Genoa, Italy, and by the Italian Ministry of Health.

\section{Treatment of neuroblastoma bearing mice with hCD31 mAb}

Tumor bearing mice were allocated randomly into three groups of seven mice each to receive intravenously (iv) the hCD31 Moon-1 purified $\mathrm{mAb}\left(\operatorname{IgG}_{2}, 450 \mu \mathrm{g} /\right.$ mouse) [17], or isotype-matched $\mathrm{IgG}_{2}$ irrelevant $\mathrm{mAb}$ (450 $\mu \mathrm{g} / \mathrm{mouse})$ for two weeks starting from day 2 after tumor cell inoculation. Treatment was administered every three days for a total of five injections. This protocol was repeated in three different experiments.

\section{Quantification of tumor growth}

Mice were sacrificed i) when they showed signs of poor health to evaluate survival or ii) the day after the conclusion of last cycle of antibody treatment, i.e. day 18 , in order to measure tumor volume and perform histological and immunohistochemical studies. Tumor volume was measured with a caliper using the following formula: Volume $=\pi / 6 \times(\mathrm{w} 1 \mathrm{x}$ w2) $(\mathrm{w} 1=$ largest tumor diameter; w2 smallest tumor diameter). For histological analyses tissue sections were stained with hematoxylin and eosin.

\section{Immunofluorescence analysis and quantifications of micro-vessel density}

Indirect immunofluorescence was performed on formalin-fixed, paraffin embedded or on cryopreserved tissue sections from mice sacrificed, or on cytospins of the HTLA-230 cell line as previously described [10]. Paraffin sections (2-4 $\mu \mathrm{m}$ thick) were processed by standard deparaffinization with xylene and hydrated in a descending ethanol series to double-distilled water. Antigen retrieval on formalin-fixed tissue section was performed using Sodium-Citrate buffer ( $\mathrm{pH}$ 6.0). Indirect immunofluorescence was performed using the following mouse monoclonal antibodies (mAbs): anti-human(h)CD31 (diluted 1/50; Dako Cytomation, Hamburg, Germany), anti-mouse(m)CD34 (1/50; Novus Biologicals, Littleton, CO, USA), anti-hOct-4 (1/50, Clone 3A5; Abcam Inc, Cambridge, USA), anti-hTenascin C (1/50; Millipore, Milan, Italy), anti-Ki-67 (1/60; Dako Cytomation), anti hE-cadherin (1/25, Clone EP700Y; Millipore), anti hN-cadherin (1/25, Clone EPR1792Y; Millipore), anti-hTwist-1 (1/50, Sigma-Aldrich, St. Louis, MO, USA), anti hHMGB-1 (1/20, Clone 1B11, Abnova, Taipei, Taiwan), anti-hVE-cadherin (1:50; Chemicon 
International, Millipore, Billerica, MA, USA), and antiHIF2 $\alpha$ (1:100; Novus Biologicals) were used. In addition, we used the following mouse mAbs ( $1 / 20$ dilution) specific for the different epitopes of hTNC, generously donated by Dr L. Zardi, Syrius Biotech, Genoa, Italy: anti BC-7, anti BC-4, anti BC-8, anti BC-6, anti BC-9, anti BC-2, antiIII8TN, anti- $\alpha / \mathrm{A} 2$, anti BC-3, anti-III12TN [18]. Isotypematched nonbinding mAbs were used in all antibodystaining experiments to exclude non specific reactivities. Slides were incubated with primary antibodies overnight at $4^{\circ} \mathrm{C}$. Secondary antibodies were goat anti-mouse IgG conjugated to Alexa-488 or goat anti-rabbit IgG Alexa-568 (1:200; Invitrogen, Germany). After washing, the slides were counterstained with 4',6'-diamidino-2- phenylindole (DAPI, Sigma-Aldrich, Milan, Italy) and cover-slipped.

EM density was assessed by anti-hCD31 or antimCD34 staining and examination of twenty to fifty microscopic fields $\left(0.5 \mathrm{~mm}^{2}\right)$ per tumor. We have shown in a previous study that the anti-hCD31 or anti-mCD34 $\mathrm{mAbs}$ used in this study are rigorously species-specific [10]. The most intense vascular areas (hotspots) were selected subjectively from each tumor section. EM with a clearly defined lumen or well-defined linear vessel shape were taken into account for EM counting.

\section{Detection of apoptotic or proliferating endothelial cells}

Apoptosis was evaluated using in situ Cell Death Detection Kit (Roche Diagnostics, Penzberg, Germany). The Terminal Deoxynucleotidyl Transferase-Mediated dUTP Nick-End Labeling (TUNEL) reaction was carried out by incubating tumor tissues with FITC-dUTP labeled nucleotides and terminal deoxynucleotidyl transferase (TdT), which catalyzes polymerization of labeled nucleotides to free 3'-OH DNA ends. Apoptotic or proliferating cells were detected by staining for TUNEL or Ki-67, respectively, in combination with hCD31. Apoptotic or proliferating EM were operationally defined as containing at least three $\mathrm{TUNEL}^{+}$or $\mathrm{Ki}-67^{+}$cells, respectively.

\section{Fluorescent In Situ Hybridization (FISH)}

Interphase FISH was performed on paraffinembedded tumor tissue sections as described [10] using rhodamine-labeled $M Y C N$-specific DNA probe (QBIOgene Inc, Hamburg, Germany) and mouse Cot1 DNA probe (Life Technologies Gibco BRL, Paisley, Scotland).

\section{PCR-Array profiling}

RNA was extracted using TRIZOL $®$ from Invitrogen (Carlsbad, CA, USA) and reverse transcribed by the ReactionReady ${ }^{\text {TM }}$ First Strand cDNA Synthesis kit (SuperArray Bioscience Corporation). Human and murine angiogenesis $\mathrm{RT}^{2}$ Profiler ${ }^{\mathrm{TM}}$ PCR Array and $\mathrm{RT}^{2}$ Real-Timer ${ }^{\mathrm{TM}}$ SyBR Green/ROX PCR was performed according to the instructions of the manufacturer on ABI Prism $^{\text {TM }} 7700$ Sequence Detector (Applied Biosystems).

\section{Cell culture and human recombinant HMGB-1 protein treatment of HTLA-230 and IMR-32 cell lines}

HTLA-230 and IMR-32 cells were maintained as previously described [10]. HTLA-230 and IMR-32 NB cells were cultured on glass slide containing dishes (Millipore) with or without human recombinant HMGB1 protein $(10 \mu \mathrm{g} / \mathrm{ml}$, Sigma-Aldrich) for $72 \mathrm{~h}$. E-cadherin, N-cadherin, Twist-1, TNC, CD31 and VE-cadherin expression were assessed by immunofluorescence staining.

\section{Flow cytometry}

TNC, CD31 and VE-cadherin expression was investigated on HTLA-230 and IMR-32 cell lines cultured with or without HMGB-1 $(10 \mu \mathrm{g} / \mathrm{ml})$ by flow cytometry. Cells were first incubated for $30 \mathrm{~min}$ at $4^{\circ} \mathrm{C}$ with primary $\mathrm{mAbs}$, then for $20 \mathrm{~min}$ with a polyclonal rabbit anti-mouse FITC-conjugated mAb (Dako Cytomation, Denmark). An isotype-matched primary $\mathrm{mAb}$ (Merk Millipore, Billerica, MA) was used as negative control. Samples were analyzed by Gallios flow cytometer and Kaluza software (Beckman Coulter, Milano, Italy). Results are expressed as MRFI calculated as ratio between MFI of specific $\mathrm{mAb}$ and MFI of irrelevant isotype-matched $\mathrm{mAb}$.

\section{In vitro hypoxia models}

HTLA-230 and IMR-32 cell lines were incubated for 24,48 and $72 \mathrm{~h}$ at $37^{\circ} \mathrm{C}$. in a hypoxia incubator (Invivo2 Hypoxia Workstation, Ruskinn Technology, UK) which was flushed by $1 \% \mathrm{O}_{2}$.

\section{Image Analysis}

Digital images were collected using a Nikon E-1000 fluorescence microscope (Nikon Instruments, Tokyo, Japan) equipped with appropriate filter sets and the Genikon imaging system software (Nikon Instruments). 


\section{Statistical analysis}

Statistical significance of differences between experimental and control groups was determined by ANOVA with Tukey's multiple comparison test using GraphPad Prism 3.0 software (GraphPad Software, Inc.). Survival curves were constructed by using the KaplanMeier method. Survival in different treatment groups was compared by using Peto's log-rank test in StatsDirect 0.1 statistical software (CamCode). Tumor volumes were compared by non parametric Mann Whitney test, one tailed (Confidence intervals 90\%). $\mathrm{P}<0.05$ was considered statistically significant.

\section{Funding}

This study was supported by Project Ricerca Finalizzata, Ministero della Salute "The primary and metastatic cancer stem cells microenvironment in neuroectodermal tumors: studies in human neuroblastoma and melanoma" (grant number G21J11000040001), Project Regione Liguria "Endotelio di derivazione tumorale: caratterizzazione e targeting immunologico a fini terapuetici" (grant number G31J10000970009), "5 per mille IRPEF Finanziamento della Ricerca Sanitaria”, and Finanziamento Ricerca Corrente. $\mathrm{CC}$ is the recipient of a fellowship from Umberto Veronesi Foundation, Milano, Italy.

\section{SUPPLEMENTARY MATERIAL}

The following supplementary material may be found in the online version of this article:

Figure S1. Anti-hCD31 Moon-1 mAb detects an epitope expressed exclusively on human endothelial cells

\section{Disclosure of potential conflicts of interest}

The authors declare no competing financial interests.

\section{REFERENCES}

1. Folkman J. Seminars in Medicine of the Beth Israel Hospital, Boston. Clinical applications of research on angiogenesis. N Engl J Med. 1995; 333:1757-1763.

2. Carmeliet P, Jain RK. Angiogenesis in cancer and other diseases. Nature. 2000; 407:249-257.

3. Eggert A, Ikegaki N, Kwiatkowski J, Zhao H, Brodeur GM, Himelstein BP. High-level expression of angiogenic factors is associated with advanced tumor stage in human neuroblastomas. Clin Cancer Res. 2000; 6:1900-1908.

4. Maniotis AJ, Folberg R, Hess A, Seftor EA, Gardner LM, Pe'er J, Trent JM, Meltzer PS, Hendrix MJ. Vascular channel formation by human melanoma cells in vivo and in vitro: vasculogenic mimicry. The American Journal of Pathology. 1999; 155:739-752.

5. Brodeur GM. Neuroblastoma: biological insights into a clinical enigma. Nat Rev Cancer. 2003; 3:203-216.

6. Maris JM, Hogarty MD, Bagatell R, Cohn SL. Neuroblastoma. Lancet. 2007; 369: 2106-2120.

7. Maris JM. Recent advances in neuroblastoma. N Engl J Med. 2010; 362:2202-2211.

8. Ribatti D, Nico B, Pezzolo A, Vacca A, Meazza R, Cinti R, Carlini B, Parodi F, Pistoia V, Corrias MV. Angiogenesis in a human neuroblastoma xenograft model: mechanisms and inhibition by tumor-derived interferon-gamma. $\mathrm{Br} \mathrm{J}$ Cancer. 2006; 94:1845-1852.

9. Pezzolo A, Parodi F, Corrias MV, Cinti R, Gambini C, Pistoia V. Tumor origin of endothelial cells in human neuroblastoma. J Clin Oncol. 2007; 25:376-383.

10. Pezzolo A, Parodi F, Marimpietri D, Raffaghello L, Cocco C, Pistorio A, Mosconi M, Gambini C, Cilli M, Deaglio S, Malavasi F, Pistoia V. Oct-4+/Tenascin C+ neuroblastoma cells serve as progenitors of tumor-derived endothelial cells. Cell Res. 2011; 21:1470-1486.

11. McGuire TF, Sajithlal GB, Lu J, Nicholls RD, Prochownik EV. In vivo evolution of tumor-derived endothelial cells. PLoS One. 2012; 7: e37138.

12. Jiang J, Tang YL, Liang XH. EMT: a new vision of hypoxia promoting cancer progression. Cancer Biol Ther. 2011; 11:714-723.

13. Singh A, Settleman J. EMT, cancer stem cells and drug resistance: an emerging axis of evil in the war on cancer. Oncogene. 2010; 29:4741-4751.

14. Scheel C, Eaton EN, Li SH, Chaffer CL, Reinhardt F, Kah KJ, Bell G, Guo W, Rubin J, Richardson AL, Weinberg RA. Paracrine and autocrine signals induce and maintain mesenchymal and stem cell states in the breast. Cell. 2011; 145:926-940.

15. Heddleston JM, Li Z, McLendon RE, Hjelmeland AB, Rich $\mathrm{JN}$. The hypoxic microenvironment maintains glioblastoma stem cells and promotes reprogramming towards a cancer stem cell phenotype. Cell Cycle. 2009; 8:3274-3284.

16. Salnikov AV, Liu L, Platen M, Gladkich J, Salnikova O, Ryschich E, Mattern J, Moldenhauer G, Werner J, Schemmer P, Büchler MW, Herr I.. Hypoxia induces EMT in low and highly aggressive pancreatic tumor cells but only cells with cancer stem cell characteristics acquire pronounced migratory potential. PLoS One 2012; 7:e46391.

17. Deaglio S., Morra M., Mallone R., Ausiello CM, Prager E, Garbarino G, Dianzani U, Stockinger H, Malavasi F. Human CD38 (ADP-ribosyl cyclase) ia a counter-receptor of CD31, an Ig superfamily member. J Immunol. 1998; 160:395-402.

18. Balza E, Siri A, Ponassi M, Caocci F, Linnala A, Virtanen I, Zardi L. Production and characterization of monoclonal antibodies specific for different epitopes of human tenascin. 
FEBS Lett. 1993; 332:39-33.

19. Mohlin S, Hamidian A, Påhlman S. HIF2 $\alpha$ and IGF2 expression correlates in human neuroblastoma cells and normal immature sympathetic neuroblasts. Neoplasia. 2013;15:328-334.

20. Paulis YW, Soetekouw PM, Verheul HM, Tjan-Heijnen VC, Griffioen AW Signalling pathways in vasculogenic mimicry. Biochim Biophys Acta. 2010;1806:18-28.

21. Kirschmann DA, Seftor EA, Hardy KM, Seftor RE, Hendrix MJ. Molecular pathways: vasculogenic mimicry in tumor cells: diagnostic and therapeutic implications. Clin Cancer Res. 2012; 18:2726-2732.

22. Thomson S, Buck E, Petti F, Griffin G, Brown E, Ramnarine N, Iwata KK, Gibson N, Haley JD. Epithelial to mesenchymal transition is a determinant of sensitivity of non-small-cell lung carcinoma cell lines and xenografts to epidermal growth factor receptor inhibition. Cancer Res. 2005; 65:9455-9462.

23. Gotzmann J, Fischer AN, Zojer M, Mikula M, Proell V, Huber H, Jechlinger M, Waerner T, Weith A, Beug H, Mikulits W. A crucial function of PDGF in TGF-betamediated cancer progression of hepatocytes. Oncogene. 2006; 25:3170-3185.

24. Graham TR, Zhau HE, Odero-Marah VA, Osunkoya AO, Kimbro KS, Tighiouart M, Liu T, Simons JW, O’Regan RM. Insulin-like growth factor-I-dependent up-regulation of ZEB1 drives epithelial-to-mesenchymal transition in human prostate cancer cells. Cancer Res. 2008; 68:24792488.

25. Su YW, Xie TX, Sano D, Myers JN. IL-6 stabilizes Twist and enhances tumor cell motility in head and neck cancer cells through activation of casein kinase 2. PLoS One. 2011;6:e19412.

26. Gherzi R, Carnemolla B, Siri A, Ponassi M, Balza E, Zardi L. Human tenascin gene. J Biol Chem. 1995; 270:34293434.

27. Carnemolla B, Castellani P, Ponassi M, Borsi L, Urbini S, Nicolo G, Dorcaratto A, Viale G, Winter G, Neri D, Zardi L. Identification of a glioblastoma-associated tenascin-C isoform by a high affinity recombinant antibody. Am J Pathol. 1999; 154:345-1352.

28. von Holst A, Egbers U, Prochiantz A, Faissner A. Neural stem/progenitor cells express 20 tenascin $C$ isoforms that are differentially regulated by Pax6. J Biol Chem. 2007; 282:9172 -9181.

29. Sun T, Zhao N, Zhao XL, Gu Q, Zhang SW, Che N, Wang $\mathrm{XH}, \mathrm{Du}$ J, Liu YX, Sun BC. Expression and functional significance of Twist1 in hepatocellular carcinoma: its role in vasculogenic mimicry. Hepatology. 2010; 51:545-556.

30. Kalluri R, Weinberg RA. The basics of epithelialmesenchymal transition. J Clin Invest. 2009; 119:14201428.

31. Schlueter C, Weber H, Meyer B, Rogalla P, Röser K, Hauke $\mathrm{S}$, Bullerdiek J. Angiogenetic signaling through hypoxia:
HMGB1: an angiogenetic switch molecule. Am J Pathol. 2005; 166:1259-1263.

32. He M, Kubo H, Ishizawa $\mathrm{K}$, Hegab AE, Yamamoto $\mathrm{Y}$, Yamamoto H, Yamaya M. The role of the receptor for advanced glycation end-products in lung fibrosis. Am J Physiol Lung Cell Mol Physiol. 2007; 293:1427-1436.

33. Ahmed N, Abubaker K, Findlay J, Quinn M. Epithelial mesenchymal transition and cancer stem cell-like phenotypes facilitate chemoresistance in recurrent ovarian cancer. Curr Cancer Drug Targets. 2010; 10:268-278.

34. Lynch J, Nolan S, Slattery C, Feighery R, Ryan MP, McMorrow T. High-mobility group box protein 1: a novel mediator of inflammatory-induced renal epithelialmesenchymal transition. Am J Nephrol. 2010; 32:590-602.

35. Sims GP, Rowe DC, Rietdijk ST, Herbst R, Coyle AJ. HMGB1 and RAGE in inflammation and cancer. Annu Rev Immunol. 2010; 28:367-388.

36. Cramer P, Hallek M. Hematological cancer in 2011: New therapeutic targets and treatment strategies. Nat Rev Clin Oncol. 2012; 9:72-74.

37. Wang R, Chadalavada K, Wilshire J, Kowalik U, Hovinga KE, Geber A, Fligelman B, Leversha M, Brennan C, Tabar V. Glioblastoma stem-like cells give rise to tumour endothelium. Nature. 2010; 468:829-833.

38. Soda Y, Marumoto T, Friedmann-Morvinski D, Soda M, Liu F, Michiue H, Pastorino S, Yang M, Hoffman RM, Kesari S, Verma IM. Transdifferentiation of glioblastoma cells into vascular endothelial cells. Proc Natl Acad Sci U S A. 2011; 108:4274-4280.

39. Seftor RE, Hess AR, Seftor EA, Kirschmann DA, Hardy KM, Margaryan NV, Hendrix MJ. Tumor cell vasculogenic mimicry: from controversy to therapeutic promise. Am J Pathol. 2012; 181:1115-1125.

40. Pàez-Ribes M, Allen E, Hudock J, Takeda T, Okuyama H, Viñals F, Inoue M, Bergers G, Hanahan D, Casanovas O. Antiangiogenic therapy elicits malignant progression of tumors to increased local invasion and distant metastasis. Cancer Cell. 2009; 15:220-231.

41. Hodi FS, O'Day SJ, McDermott DF, Weber RW, Sosman JA, Haanen JB, Gonzalez R, Robert C, Schadendorf D, Hassel JC, Akerley W, van den Eertwegh AJ, Lutzky J, Lorigan P, Vaubel JM, Linette GP, et al. Improved survival with ipilimumab in patients with metastatic melanoma. $\mathrm{N}$ Engl J Med. 2010; 363:711-723.

42. Ebos JM, Pili R Mind the gap: potential for rebounds during antiangiogenic treatment breaks. Clin Cancer Res. 2012; 18:3719-3721.

43. Blagosklonny MV. Hypoxia-inducible factor: Achilles' heel of antiangiogenic cancer therapy. Int J Oncol. 2001;19:257262.

44. Leontieva OV, Natarajan V, Demidenko ZN, Burdelya LG, Gudkov AV, Blagosklonny MV. Hypoxia suppresses conversion from proliferative arrest to cellular senescence. Proc Natl Acad Sci U S A. 2012;109:13314-13318. 
45. Sun B, Zhang D, Zhang S, Zhang W, Guo H, Zhao $\mathrm{X}$. Hypoxia influences vasculogenic mimicry channel formation and tumor invasion-related protein expression in melanoma. Cancer Lett. 2007; 249:188-197.

46. Soda Y, Myskiw C, Rommel A, Verma IM. Mechanisms of neovascularization and resistance to anti-angiogenic therapies in glioblastoma multiforme. J Mol Med. 2013;91: 439-448.

47. Blagosklonny MV. Antiangiogenic therapy and tumor progression. Cancer Cell. 2004;5:13-17.

48. Yang J, Mani SA, Donaher JL, Ramaswamy S, Itzykson RA, Come C, Savagner P, Gitelman I, Richardson A, Weinberg RA. Twist, a master regulator of morphogenesis, plays an essential role in tumor metastasis. Cell. 2004; 117:927-939.

49. Martin A, Cano A. Tumorigenesis: Twist1 links EMT to self-renewal. Nat Cell Biol. 2010; 12:924-925.

50. Sun T, Sun BC, Zhao XL, Zhao N, Dong XY, Che N, Yao Z, Ma YM, Gu Q, Zong WK, Liu ZY. Promotion of tumor cell metastasis and vasculogenic mimicry by way of transcription coactivation by Bcl-2 and Twist1: a study of hepatocellular carcinoma. Hepatology. 2011; 54:1690-1706.

51. Krysko DV, Garg AD, Kaczmarek A, Krysko O, Agostinis $\mathrm{P}$, Vandenabeele P. Immunogenic cell death and DAMPs in cancer therapy. Nat Rev Cancer. 2012; 12:860-875.

52. Hamada T, Torikai M, Kuwazuru A, Tanaka M, Horai N, Fukuda T, Yamada S, Nagayama S, Hashiguchi K, Sunahara N, Fukuzaki K, Nagata R, Komiya S, Maruyama I, Fukuda T, Abeyama K. Extracellular high mobility group box chromosomal protein 1 is a coupling factor for hypoxia and inflammation in arthritis. Arthritis Rheum. 2008; 58:2675-2685.

53. Reismann M, Wehrmann F, Schukfeh N, Kuebler JF, Ure $\mathrm{B}$, Glüer S. Carbon dioxide, hypoxia and low $\mathrm{pH}$ lead to overexpression of c-myc and HMGB-1 oncogenes in neuroblastoma cells. Eur J Pediatr Surg. 2009;19: 224- 227.

54. Kang R, Zhang Q, Zeh HJ 3rd, Lotze MT, Tang D. HMGB1 in Cancer: Good, Bad, or Both? Clin Cancer Res. 2013; 19:4046-4057.

55. van Beijnum JR, Nowak-Sliwinska $P$, van den Boezem E, Hautvast P, Buurman WA, Griffioen AW. Tumor angiogenesis is enforced by autocrine regulation of highmobility group box 1. Oncogene. 2013; 32:363-374.

56. Nagaharu K, Zhang X, Yoshida T, Katoh D, Hanamura N, Kozuka Y, Ogawa T, Shiraishi T, Imanaka-Yoshida K. Tenascin $\mathrm{C}$ induces epithelial-mesenchymal transition-like change accompanied by SRC activation and focal adhesion kinase phosphorylation in human breast cancer cells. Am J Pathol. 2011; 178:754-763.

57. Huttunen HJ, Kuja-Panula J, Rauvala H. Receptor for advanced glycation end products (RAGE) signaling induces CREB-dependent chromogranin expression during neuronal differentiation. J Biol Chem. 2002; 277:38635-38646.

58. Mohan N, Banik NL, Ray SK. Combination of N-(4- hydroxyphenyl) retinamide and apigenin suppressed starvation-induced autophagy and promoted apoptosis in malignant neuroblastoma cells. Neurosci Lett. 2011; 502:24-29.

59. Liu Z, Sun B, Qi L, Li H, Gao J, Leng X. Zinc finger E-box binding homeobox 1 promotes vasculogenic mimicry in colorectal cancer through induction of epithelial-tomesenchymal transition. Cancer Sci. 2012; 103:813-820.

60. Korkaya H, Kim GI, Davis A, Malik F, Henry NL, Ithimakin S, Quraishi AA, Tawakkol N, D’Angelo R, Paulson AK, Chung S, Luther T, Paholak HJ, Liu S, Hassan KA, Zen Q, Clouthier SG, Wicha MS Activation of an IL6 inflammatory loop mediates trastuzumab resistance in HER $2+$ breast cancer by expanding the cancer stem cell population. Mol Cell. 2012; 47:570-584.

61. Tang Z, Lu B, Hatch E, Sacks SH, Sheerin NS. C3a mediates epithelial-to-mesenchymal transition in proteinuric nephropathy. J Am Soc Nephrol. 2009; 20:593-603.

62. Suetsugu-Maki R, Maki N, Fox TP, Nakamura K, Cowper Solari R, Tomlinson CR, Qu H, Lambris JD, Tsonis PA. A complement receptor $\mathrm{C} 5 \mathrm{a}$ antagonist regulates epithelial to mesenchymal transition and crystallin expression after lens cataract surgery in mice. Mol Vis. 2011; 17:949-964. 